Manufatura açucareira colonial:

constituição, desenvolvimento e particularidade.

Gabriel Magalhães Beltrão

Resumo: O presente artigo tem por objetivo analisar a manufatura açucareira colonial com o intuito de buscar apreender suas particularidades em relação às manufaturas clássicas estudadas por Marx. Através de recursos iconográficos e de relatos de época, buscaremos evidenciar o caráter manufatureiro já existente desde os primeiros engenhos no século XVI, enfatizando os meios de trabalho e a organização da produção que eram utilizados na produção para exportação. $\mathrm{O}$ aprimoramento manufatureiro ocorrido no século XVII será analisado em suas implicações sobre os trabalhadores e a produtividade, demonstrando-se que as relações escravistas de produção eram compatíveis com progresso técnico e organizativo típicos do capitalismo mercantil. A cooperação baseada na divisão do trabalho - manufatura - é apresentada não somente como compatível com o trabalho escravo, mas também como uma necessidade para a utilização sistemática deste tipo de relações de produção. Tais relações de produção aprofundam ainda mais a separação do trabalho manual em relação ao trabalho intelectual, característica marcante da manufatura, e, por conseguinte, imprimem uma particularidade à manufatura açucareira colonial em relação à manufatura europeia.

Palavras-chave: Escravismo. Manufatura açucareira. Sociologia do desenvolvimento.

Abstract: The objective of this article is to analyze the colonial manufacture of sugar, with the intention of apprehending its particularities in relation to the classic manufactures studied by Marx. Through iconographic resources and accounts of the time, we seek to demonstrate the manufacturing character already existing since the first sugar mills in the 16th century, emphasizing the means of labor and the organization of production which were utilized in the production for export. The improvement of the manufacture that occurred in the 17th century, will be analyzed in its implications for the workers and the productivity, indicating

${ }^{1}$ Bacharel em Ciências Sociais e mestre pelo Programa de Pós-Graduação em Sociologia do Instituto de Ciências Sociais da Universidade Federal de Alagoas,

gabriel bolinha@hotmail.com.

Latitude, vol. 5, no 1, pp. 133-158, 2011

DOI: https://doi.org/10.28998/2179-5428.20110106 


\section{Manufatura açucareira colonial: constituição, desenvolvimento e particularidade.}

that slave relations of production were compatible with organizational and technical progress typical of merchant capitalism. The cooperation based on the division of labor - manufacture - is presented not only as compatible with slave labor, but also as a necessity for a systematic utilization of this type of relations of production. Such relations of production deepen even further the separation of manual labor and intellectual labor, a significant characteristic of manufacture, and consequently instill a particularity in colonial manufacture of sugar in relation to the European manufacture.

Keywords: Slavery; Manufacturing sugar; Sociology of development.

Com o objetivo de colonizar as novas terras para evitar a sua perda para outras nações ultramarinas e de engendrar uma produção colonial que satisfizesse o capital mercantil, a Coroa Portuguesa deu início em meados do século XVI ao estímulo à edificação de engenhos de açúcar na costa do Brasil. O grande impulso à colonização se deu mediante a distribuição de terras àqueles que tivessem a capacidade de trabalhá-las. O princípio que regia a adoção das sesmarias era o aproveitamento, que estava, por sua vez, diretamente relacionado à capacidade do indivíduo em possuir escravos. A escolha do açúcar não foi fortuita: o mesmo já era no século XVI uma especiaria muito lucrativa, sendo desde o século XIV explorado pelos capitais genoveses e venezianos em Chipre, Creta e na Sicília. Portugal, por sua vez, adquiriu experiência na produção açucareira a partir das ilhas de Cabo Verde e Açores. Estes antecedentes históricos indicam que os meios de produção e a organização do trabalho, trazidos pelos portugueses através dos primeiros engenhos, não constituíram de imediato uma inovação produtiva, mas apenas uma transferência de tecnologia e de método de organização da força de trabalho já universalizadas e imprescindíveis para se instaurar a produção e comercialização em massa deste produto. As próprias relações escravistas de produção advieram dessas experiências anteriores, que estão diretamente relacionadas com o capital mercantil em plena expansão. O Brasil, portanto, maximiza ao extremo as experiências já possuídas pelos portugueses em suas colônias insulares, recebendo a tecnologia, o modelo de organização do trabalho e o escravismo como bases para a produção do açúcar.

Buscaremos demonstrar as características dos engenhos erigidos no início da colonização, e, posteriormente, refletir acerca das principais inovações produtivas ocorridas no decorrer do século XVII, marcado pelo aprimoramento manufatureiro resultado na maior decomposição do trabalho no interior da planta fabril. 


\section{Os primeiros engenhos de açúcar}

Segundo o historiador Ruy Gama, provavelmente o fabrico do açúcar no início da colonização se desenvolvia de forma semelhante à produção siciliana, retratada por Stradanus abaixo.

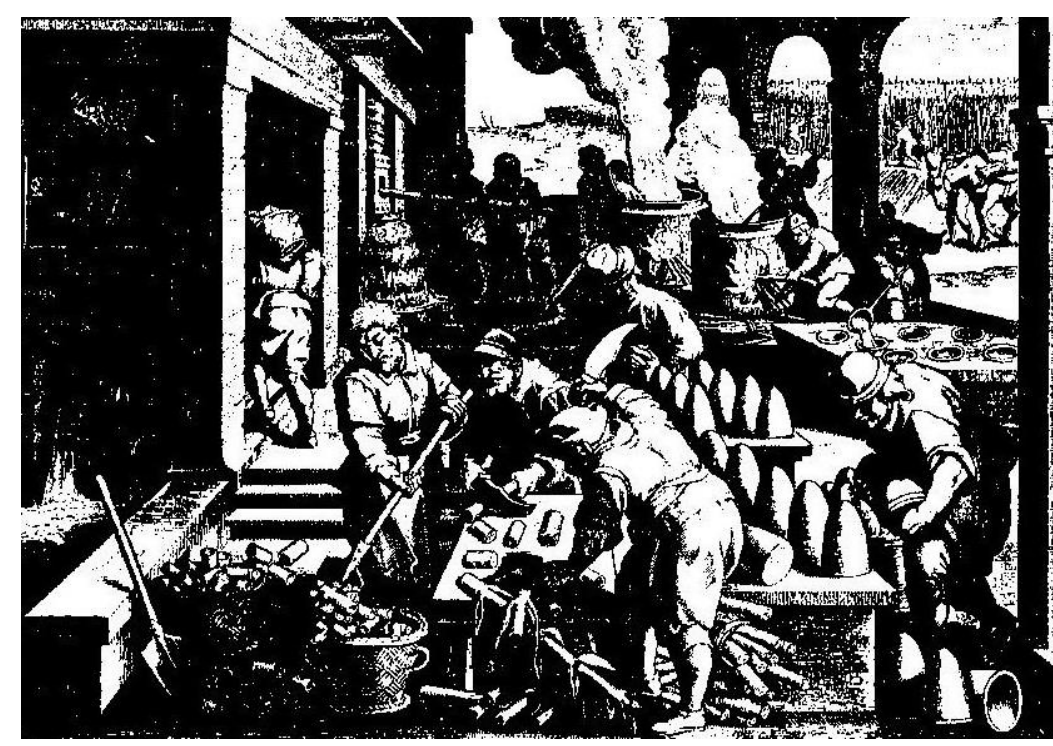

Ilustração 1 - Ilustração de Stradanus que retrata a fabricação de açúcar na Sicília durante o século XVI. (Fonte: GAMA, 1983, p. 90)

Através desta ilustração podemos perceber que a produção brasileira de açúcar já surge com um caráter manufatureiro, que seria aprimorado no decorrer do século XVII em virtude de inovações na maquinaria de extração de caldo. Por sinal, Marx afirma em $\mathrm{O}$ Capital que o período histórico da manufatura é compreendido entre meados do século XVI até o último terço do século XVIII, estando, portanto, inserida a produção de açúcar colonial neste histórico de mais de duzentos anos.

O que caracteriza a produção manufatureira é a decomposição do trabalho artesanal e a conseqüente unilateralização dos trabalhadores envolvidos no processo de trabalho; as forças produtivas individuais tornam-se partes componentes de um órgão ou mecanismo: o trabalhador coletivo combinado. No caso europeu estudado por Marx, tais forças produtivas individuais perdem o saberfazer pleno que caracteriza um artesão, capaz de executar todas as operações necessárias à fabricação de um dado valor de uso. No nosso caso, os escravos negros que são obrigados a se inserir na produção manufatureira do engenho não dispunham do saber-fazer pleno à produção do açúcar, como fora o caso do 


\section{Manufatura açucareira colonial: constituição, desenvolvimento e particularidade.}

artesão europeu estudado por Marx; foram eles introjetados sob a coerção do látego na engrenagem do trabalhador coletivo combinado, para a produção de um produto que sequer era conhecido por eles. Trata-se de uma peculiaridade própria à nossa formação colonial, onde não há o processo histórico de acumulação primitiva de capital enquanto pressuposto necessário à constituição da relação capital. Enquanto na Europa o surgimento da manufatura é resultado do processo de separação dos trabalhadores dos seus meios de produção, opondo-se-lhes como capital, na manufatura açucareira americana a relação de produção constituída tem na coerção extra-econômica o fundamento do processo produtivo. $\mathrm{O}$ trabalho escravo é uma necessidade em virtude dos desígnios que presidem a colonização dos trópicos americanos, erigindo-se relações de produção pré-capitalistas que satisfaziam o capital mercantil. Ainda assim, isto não invalida para nós o estudo marxiano a respeito das consequências da divisão manufatureira do trabalho sobre os trabalhadores, afinal, tal como os assalariados europeus, os escravos também sofrem com o processo de unilateralização e atrofia característico desta forma de organização do trabalho. Ambos tornam-se uma anomalia apta à execução célere de operações parciais, reprimidos em desenvolver suas plenas capacidades produtivas.

Enquanto os assalariados europeus perdem a condição de artesãos que possuíam outrora, atrofiando-se, os escravos dos engenhos - que já haviam perdido a própria propriedade sobre si mesmos - integram o trabalhador coletivo na condição precedente de despossuídos de tudo, inclusive de conhecimentos básicos necessários ao fabrico do açúcar. Nesta condição de trabalhadores escravos desqualificados, eles apenas poderiam se inserir na produção fabril caso suas operações fossem as mais simples possíveis, eminentemente manuais e carentes de maiores complexidades. "A ignorância, a incapacidade, a falta de atenção e cuidado com que se maneja a fabricação do açúcar são de pasmar" (PRADO JR. 2012, p. 146). Neste sentido, a manufatura pode ser considerada como uma condição indispensável para a utilização produtiva da força de trabalho escrava na parte fabril do engenho, já que se trata de uma força de trabalho que não dispõe de qualquer qualificação e predisposição necessária para adquiri-la. A decomposição do processo produtivo artesanal do açúcar numa série de funções parciais, simples e eminentemente manuais era imprescindível para a inserção dos escravos na produção. As profissões do engenho que exigiam qualificação eram quase sempre destinadas aos poucos trabalhadores livres existentes, tais como os mestres do açúcar e os purgadores. No decorrer da nossa análise utilizaremos o estudo de Marx sobre as consequências universais da manufatura, evidenciando, no entanto, peculiaridades próprias à manufatura baseada no trabalho escravo e aquelas oriundas da matériaprima beneficiada.

Seguindo o raciocínio de Marx, a manufatura põe fim ao artesão sem, contudo, superar a artesanalidade: 
[...] antes de mais nada, a análise do processo de produção em suas fases particulares coincide inteiramente com a decomposição de uma atividade artesanal em suas diversas operações parciais. Composto ou simples, a execução continua artesanal e portanto dependente da força, habilidade, rapidez e segurança do trabalhador individual no manejo do seu instrumento. $O$ ofício permanece a base. (MARX, 1983, p. 269)

Observando a ilustração de Stradanus, verificamos um contingente significativo de trabalhadores envolvidos na execução de operações parciais do fabrico do açúcar. Trata-se de um forte indício do caráter manufatureiro dos primeiros engenhos coloniais, afinal, “(...) a divisão manufatureira do trabalho desenvolve o crescimento do número de trabalhadores empregados numa necessidade técnica" (MARX, 1983, p. 282). Como podemos constatar na ilustração, três deles executam atividades relacionadas à limpeza e ao corte da matéria-prima, utilizando-se de duas ferramentas distintas: uma apropriada para o corte da canade-açúcar e outra para a sua arrumação em cestas. Dois dos três trabalhadores da limpeza se especializam no corte da cana, ao passo que apenas um fica encarregado de arrumar as cestas com as canas em pequenos pedaços. Some-se a esses três trabalhadores um responsável apenas por transportar as cestas de cana para a moenda hidráulica ${ }^{2}$. Trata-se de operações simples capaz de serem executadas por qualquer pessoa e a qualquer tempo, entretanto, o objetivo do plantador quando impõe a divisão do trabalho no interior do engenho é que tais operações sejam realizadas por "trabalhadores detalhistas" (MARX, 1983, p. 269). Isso porque "A repetição contínua da mesma ação limitada e a concentração da atenção nela ensinam, conforme indica a experiência, a atingir o efeito útil desejado com um mínimo de gasto de força" (MARX, 1983, p. 269). A virtuosidade dos trabalhadores detalhistas advém justamente desta execução repetitiva de operações simples, acrescida no caso do engenho da ameaça constante do açoite do feitor de moenda a exigir a intensidade desejada pela engrenagem produtiva.

Como a base da manufatura ainda é a artesanalidade, os limites ao aumento da produtividade do trabalho são de natureza antropomórfica: a força, a

${ }^{2}$ Ferlini contabiliza a quantidade de trabalhadores escravos envolvidos na extração de caldo antes e depois da adoção do sistema de entrosas, que veremos mais a frente. Segundo ela, este contingente de três escravos de limpeza da cana mais um de condução para a moenda não se modificou com a inovação do maquinário (Cf. FERLINI,1988, p. 112 e 113). Modificações na limpeza e arrumação da cana para moagem provavelmente só sofreram alterações com a adoção das esteiras automáticas, surgidas no processo de industrialização do final do século XIX. 


\section{Manufatura açucareira colonial: constituição, desenvolvimento e particularidade.}

habilidade e a rapidez dos trabalhadores manuais. A parcelização do trabalho que inclui desde aquelas operações demasiadamente simples até aquelas que requerem habilidades especiais ou conhecimento - busca explorar até o limite o aumento da produtividade de base antropomórfica ${ }^{3}$, limites estes que apenas serão superados com o surgimento da maquinaria (revolução industrial). "A unilateralidade e mesmo a imperfeição do trabalhador parcial tornam-se sua perfeição como membro do trabalhador coletivo" (MARX, 1983, p. 276), diz Marx, afinal, a perda do pleno saber-fazer e a conseqüente estreiteza do trabalhador o torna mais produtivo, produtividade esta inimaginável à luz de uma produção artesanal. Seja em operações parciais mais simples ou mais complexas, a chave para a manufatura aumentar a produtividade do trabalho reside na especialização da execução de suas diversas operações, dado que a repetição produz um sujeito autômato no seu fazer cotidiano.

Dando prosseguimento à nossa análise da ilustração, foquemos agora nossa atenção sobre a extração propriamente dita do caldo da cana-de-açúcar. Apenas em meados do século XVII é que surge um maquinário de extração de caldo criado especificamente para a cana-de-açúcar. Até então se utilizavam nos engenhos de "máquinas tomadas de empréstimos de outras oficinas rurais, como eram os moinhos de cereais e as prensas" (GAMA, 1979, p. 91). No caso da ilustração de Stradanus, verifica-se justamente a utilização de dois tipos de máquinas: um moinho romano (atafona) movido à água e uma prensa de largar-tórculo de tração humana ${ }^{4}$. Mesmo que tais máquinas adaptadas à moagem da cana-de-açúcar na Sicília não tivessem sido utilizadas largamente no Brasil, uma característica geral de todas as adaptações utilizadas era a parca eficiência na extração do caldo, reduzindo bastante a produtividade nesta etapa da produção, pois estas não conseguiam impor suficiente pressão à cana-de-açúcar - incapazes, portanto, de aumentar o índice de extração de caldo por tonelada e proporcionar maior regularidade na operação dessas máquinas. Além disso, a utilização de duas

\footnotetext{
3 “Precisamente por continuar sendo a habilidade manual a base do processo de produção é que cada trabalhador é apropriado exclusivamente para uma função parcial e sua força de trabalho é transformada por toda vida em órgão dessa função parcial" (MARX, 1983, p. 269). Quanto maior for a familiaridade do trabalhador com a sua operação parcial, tanto maior será a celeridade com que executa as suas ações. Isto é válido tanto para as operações mais complexas quanto àquelas as mais simples.

${ }^{4}$ Ver ilustração em GAMA, 1979, p. 95 e 97.

${ }^{5}$ Segundo Ruy Gama, é mais provável que a extração de caldo nas Américas tenha ocorrido com a utilização de duas outras máquinas tomadas de empréstimos de outros ramos. Tais máquinas seriam a moenda de dois rolos na horizontal, movida à água, e as prensas (alçapremas) de propulsão animal. Em meados do século XVII tais máquinas foram substituídas pela moenda de entrosas (ou palitos), surgidas especificamente para a extração do caldo da cana-de-açúcar.
} 
máquinas impunha a necessidade de muita mão-de-obra escrava, tanto para a operação de ambas as máquinas quanto para o deslocamento da matéria-prima de uma para outra, o que aumentava significativamente os custos de produção. Segundo Ferlini, cinco trabalhadores eram envolvidos na etapa de moagem nos primeiros engenhos coloniais: dois no manuseio da moenda de dois rolos horizontais, um para condução do bagaço à prensa, um para operação desta prensa e, por fim, um responsável por retirar o bagaço do recinto. Havia, portanto, uma complementariedade entre as duas máquinas utilizadas para a extração do caldo: a cana que passa pelos rolos horizontais tinha o bagaço prensado nas alçapremas segue ilustrações abaixo.

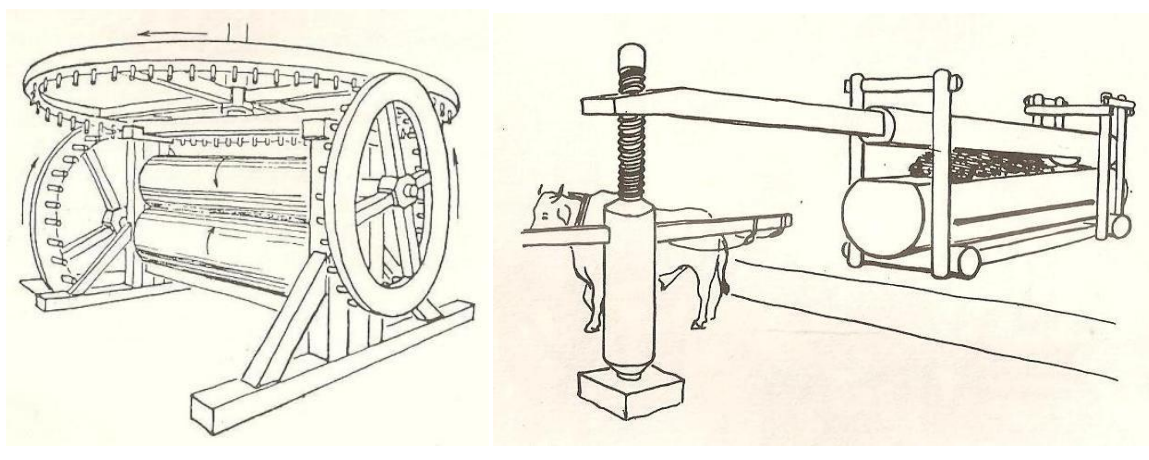

Ilustração 2 - Duplo maquinário para extração de caldo nos primeiros engenhos brasileiros: a cana inicialmente era passada por diversas vezes entre os rolos horizontais da moenda hidráulica, sendo em seguida o seu bagaço prensado na prensa (alçaprema) de tração animal (Fonte: FERLINI, 1988, p. 110).

A divisão manufatureira do trabalho busca superar ao máximo os poros improdutivos característicos da produção artesanal, onde um mesmo trabalhador executa diversas funções, o que ocasiona perdas com mudanças de ferramentas e mesmo com deslocamentos necessários no interior da oficina. Na manufatura o objetivo precípuo é a superação de tais fissuras na produção, vislumbrando tornar o cotidiano do trabalhador o mais contínuo possível, de forma a evitar interrupções no seu fluxo de trabalho. Para que isto seja atingindo, busca-se impor ao trabalhador um certo sedentarismo que ponha fim aos descolamentos no ambiente laborativo, de maneira que se mantenha fixo e concentrado na execução de sua operação parcial. O consumo da força de trabalho deve ser constante e contínuo, evitando interrupções que para o capital significa um dispêndio improdutivo da força de trabalho.

Tal continuidade na produção do trabalhador individual deve ser igualmente verificada no trabalhador coletivo combinado, caso contrário, pelo menos alguns órgãos do mecanismo terão suas atividades interrompidas em virtude do rompimento da continuidade na engrenagem geral. Consideremos, 


\section{Manufatura açucareira colonial: constituição, desenvolvimento e particularidade.}

portanto, a continuidade do ponto de vista do indivíduo isolado e a continuidade do ponto de vista trabalhador coletivo combinado. Neste último caso, o conjunto das operações parciais justapostas no espaço da oficina deve ser executado de forma a evitar interrupções na produção como um todo, o que pode ocorrer caso algum membro da engrenagem produza além ou aquém do estabelecido pela experiência em uma dada unidade de tempo; tal descompasso também pode advir do encurtamento acentuado do tempo exigido para o deslocamento do objeto de trabalho, hipótese em que o mecanismo global necessita ser revisado. Portanto, o mecanismo do trabalhador coletivo combinado é maculado sempre que o tempo de trabalho necessário - seja para a execução de alguma operação parcial ou para a passagem do objeto de trabalho de um trabalhador para o outro - em algum ponto do mecanismo global não corresponder às expectativas vigentes num dado momento. Nas palavras de Marx:

Estabelecer e manter a conexão entre as funções isoladas requer transporte ininterrupto do artigo de uma mão para outra e de um processo para outro. Do ponto de vista da grande indústria, isso se apresenta como uma limitação característica, custosa e imanente ao princípio da manufatura. (...) O tempo de trabalho necessário para alcançar o efeito útil ambicionado em cada processo parcial é fixado de acordo com a experiência e o mecanismo global da manufatura baseia-se no pressuposto de que em dado tempo de trabalho um resultado dado é obtido. (1983, p. 273)

O caso dos primeiros engenhos não é diferente: a articulação precisa entre as diversas operações parciais é fundamental para a continuidade da produção do açúcar. Entretanto, segundo Vera Lúcia Amaral Ferlini, especificamente na etapa de extração de caldo, esta continuidade era bastante prejudicada em função da necessidade de utilização de duas máquinas. Isso ocorria pelo fato da matériaprima ter que ser deslocada da moenda horizontal para as alçapremas, ao invés da extração ocorrer em uma única máquina. Além do transporte ferir bastante o fluxo contínuo almejado, a própria operação das máquinas não contribuía neste sentido: o sistema de rolos horizontais apenas era alimentado de um lado, exigindo a transferência do bagaço de trás para frente, o que prejudicava bastante a produção num ritmo contínuo e aumentava excessivamente os custos de produção, afinal de contas, duas forças de trabalho tinham que ser direcionadas para a operação de uma única máquina cuja a eficiência era bastante reduzida; o próprio controle coercitivo por parte dos feitores de moenda era dificultado nestas condições técnicas, já que deslocamentos excessivos de trabalhadores sempre implica na 
possibilidade dos mesmos remancharem na execução de suas atribuições, exigindo, portanto, maior atenção por parte daqueles cuja responsabilidade é exigir intensidade e continuidade ao trabalho alienado. As alçapremas, por sua vez, eram movidas por uma dupla de bois e sua operação final era bastante morosa, contribuindo também para tornar a continuidade bastante sofrível. Somente com o advento das moendas de três rolos na vertical durante o século XVII é que a moenda adquiriu maior continuidade e produtividade, como veremos mais à frente.

Já na etapa de cozimento do caldo, evidencia-se mais uma vez o quanto a manufatura açucareira ainda estava imatura, possuindo apenas duas caldeiras para a purificação, evaporação e cozimento do caldo. Apesar desta parca multiplicação de recipientes - o que demonstra uma divisão do trabalho ainda pequena, em status nascendi - , a existência de duas caldeiras - e não de apenas uma - já evidencia a multiplicação de recipientes tendo em vista proporcionar maior continuidade ao processo. Com duas caldeiras o fluxo (ou vazão) de caldo já é maior à medida que a purificação/evaporação na primeira caldeira conduz o mel para o cozimento na segunda, liberando a primeira, por conseguinte, para o recebimento de mais caldo a ser purificado e evaporado. Nas palavras de Ruy Gama:

A multiplicação das tachas parece ser a primeira solução técnica adequada à passagem da produção artesanal - ainda existente em nossos pequenos engenhos rapadureiros - para a produção manufatureira. Operando com uma única tacha, o engenho libera uma partida de massa a cada três ou quatro horas. Com o uso de duas ou mais esse tempo de espera pode diminuir e a produção vai tendendo para um fluxo contínuo (GAMA, 1983, p. 91).

A duplicação das caldeiras proporciona ganho na produtividade pelo fato do tempo ocioso nas demais etapas ser reduzido: com uma só caldeira o tempo total de cozimento (de 3 a 4 horas) seria quase sinônimo de interrupção dos trabalhos antecedentes (limpeza e moagem da cana). Com a duplicação das caldeiras, diferentemente, pode-se supor que a matéria-prima permaneça a metade do tempo (1:30 a 2 horas) em cada uma delas, fato que permite a liberação da primeira caldeira para o recebimento de mais caldo de forma antecipada mantendo-se, por conseguinte, a moagem ininterruptamente, mesmo que numa intensidade controlada para evitar excesso de caldo. Em outros termos: a baldeação de uma caldeira para outra permite que o objeto de trabalho legado pela moenda seja despejado na primeira caldeira, o que aciona novamente a produção de caldo 


\section{Manufatura açucareira colonial: constituição, desenvolvimento e particularidade.}

que alimentará a cozinha cerca de duas horas depois. Surge a simultaneidade ${ }^{6}$ das operações que contrasta com a interrupção temporária da moagem durante boa parte do tempo em que o caldo permanecia nas caldeiras, aspecto característico de uma produção artesanal onde o fator tempo não joga peso decisivo sobre a fabricação.

Na produção artesanal das engenhocas de rapadura, a existência de uma única caldeira permite que o mesmo trabalhador acumule diversas funções, pois enquanto o caldo coze por três ou quatro horas, pode ele limpar a cana ou mesmo ajudar na moagem. Neste caso a divisão do trabalho inexiste ou é bastante flexível (na hipótese de uma produção familiar), não havendo a unilateralização do trabalhador detalhista que proporciona o aumento da produtividade do trabalho. Ademais, a descontinuidade da produção é a regra: não há a simultaneidade na execução das operações parciais nem o fluxo contínuo do objeto de trabalho por suas etapas sucessivas, espacial e temporalmente distintas. A chegada do objeto de trabalho a uma certa etapa do processo produtivo interrompe as atividades antecedentes por determinado tempo, a ponto de permitir que o "cozinhador" execute outras operações nesta grande paralisação da produção. Temos aqui a figura clássica de um artesão, participando integralmente do processo produtivo de um valor de uso.

Vale dizer também que nestes primeiros engenhos o mestre do açúcar ainda executava as operações manuais componentes do cozimento do caldo, contando com o auxílio de um ajudante - provavelmente um trabalhador livre. O saber-fazer acumulado pelo mestre ainda não havia sido materializado numa seqüência produtiva de propriedade do plantador, seqüência esta que o despojará do trabalho manual que será dividido em operações parciais e entregues aos escravos, restando-lhe a observação e a atuação em todas as etapas do processo de cozimento como trabalhador qualificado - dotado de conhecimentos aos quais os escravos eram alijados. Neste momento o cozimento do caldo ainda está muito próximo da produção artesanal, desempenhando o mestre o conjunto de operações parciais ainda unificado.

Pode-se concluir que os primeiros engenhos coloniais erigidos ainda no século XVI possuíam uma organização manufatureira do trabalho, ainda que esta fosse pouco desenvolvida em virtude da debilidade crônica na etapa de extração

\footnotetext{
6 "A observação de determinado quantum de matéria-prima (...) mostra que ela percorre, nas mãos de diferentes trabalhadores parciais, uma seqüência cronológica de fases de produção até chegar a sua figura final. Mas se observarmos pelo contrário a oficina como um mecanismo global, vemos que a matéria-prima se encontra simultaneamente em todas as suas fases de produção de uma vez. (...) De uma sucessão no tempo, os diversos processos graduais transformam-se em uma justaposição no espaço. Daí o fornecimento de mais mercadorias no mesmo período de tempo" (MARX, 1983, p. 273).
} 
de caldo, entrave este que foi superado em meados do século XVII como veremos a seguir.

\section{Inovação tecnológica e aprimoramento manufatureiro}

Diz Marx em O Capital que o período manufatureiro logra êxito na busca por reduzir o tempo de trabalho necessário à produção da mercadoria fundamentalmente em função da divisão do trabalho, mas que esporadicamente também chegou a "desenvolver a utilização de máquinas, sobretudo para certos processos iniciais simples que têm de ser executados massivamente e com grande emprego de força" (MARX, 1983, p. 275). Como vimos acima, o emprego de máquinas rústicas adaptadas de outras oficinas para a extração de caldo data desde os primeiros engenhos brasileiros surgidos ainda no século XVI. Tais adaptações, entretanto, não extraíam de forma satisfatória o caldo da cana, além do duplo procedimento quebrar significativamente a continuidade da manufatura, exigindo deslocamentos excessivos e uma quantidade exagerada de trabalhadores escravos. A própria complexificação da divisão do trabalho na etapa de cozimento do caldo estava presa às limitações da etapa de moagem, impossibilitando a intensificação da decomposição das operações de cozimento em uma circunstância de carência de matéria-prima proporcionada por seu antecedente temporal - moagem. Neste sentido, Ruy Gama conclui que "a atividade crítica, naqueles engenhos, era a moagem" (GAMA, 1983, p. 91), marcada por baixa eficiência, descontinuidade e excesso de custos de produção com força de trabalho escrava utilizada em deslocamentos.

Essas dificuldades são superadas no decurso do século XVII quando surge o sistema de entrosas - também conhecido como moenda "palitos"7. Trata-se de uma moenda criada especificamente para a cana-de-açúcar, pondo fim aos problemas até então existentes nesta etapa da fabricação. O êxito deste novo maquinário para a manufatura açucareira se expressa no longo período quando sua utilização foi absoluta, desde o século XVII adentrando pelo século XIX. Discorrendo sobre essa inovação tecnológica, diz Gorender:

Diante da demanda crescente de açúcar no mercado europeu, configurava-se um gargalo tecnológico, rompido, afinal, por volta de 1610, pela

\footnotetext{
7 “Sua invenção é atribuída a Gonzales de Velosa, senhor de engenho em Hispanhola no século XVI, mas teria chegado ao Brasil procedente do Peru, trazida por um padre espanhol, no início do século XVII" (GAMA, 1983, p. 125).
} 


\section{Manufatura açucareira colonial: constituição, desenvolvimento e particularidade.}

introdução da moenda de três cilindros verticais de madeira com 'entrosas' [...] A moagem se tornou mais rápida e se podia espremer a cana duas vezes, por ambos os lados, com pouco gasto de trabalho. [...] A nova moenda prevaleceu e difundiu-se por exigir menor investimento e ser mais produtiva (GORENDER, 2011, p. 136).

Importante atentar para o momento histórico em que tal moenda surge e se dissemina, momento este marcado pelo monopólio português da comercialização do açúcar no mercado europeu, o que garantia lucros exorbitantes para os comerciantes e muitos dividendos para a Coroa lusitana.

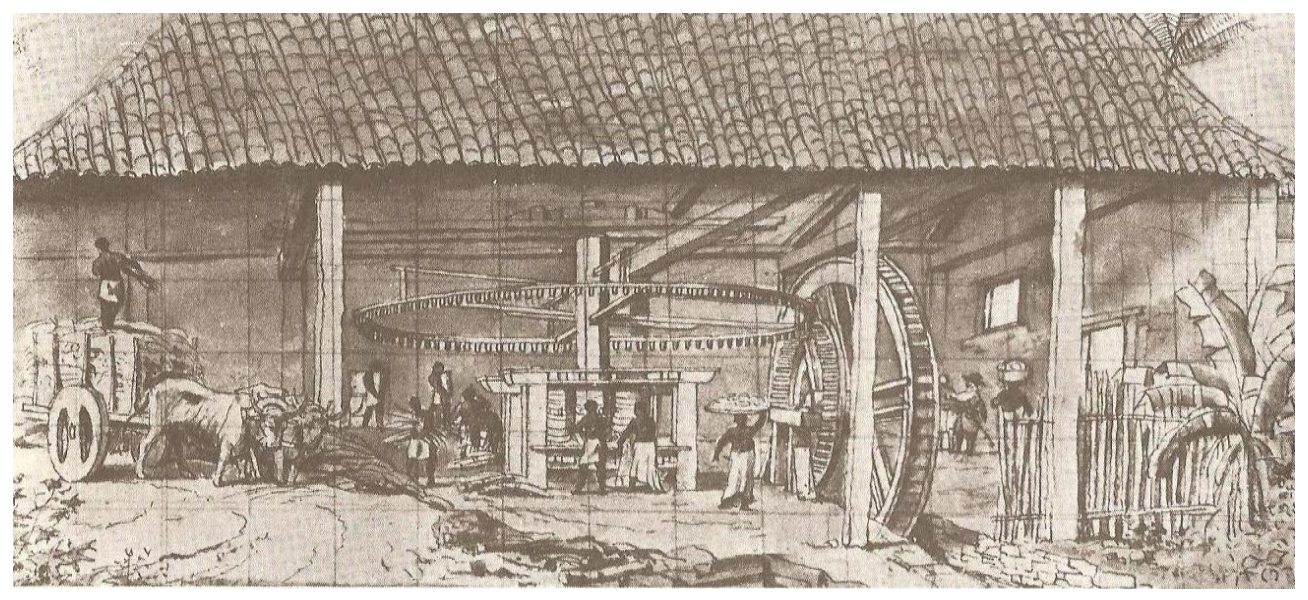

Ilustração 3 - Moenda de entrosas movidas à força hidráulica. A altura dos rolos verticais estava diretamente relacionada à estatura dos operadores escravos (Fonte: GAMA, 1983, p. 124).

O sistema de entrosas proporcionou o aumento da produtividade do trabalho tanto pela maior eficiência do maquinário8 quanto pelo ganho em termos

\footnotetext{
8 As informações a respeito da quantidade de vezes que a cana passava entre os rolos do sistema de entrosas são bastante desencontradas entre os autores que utilizamos para este texto. No entanto, é consenso entre todos eles o ganho de eficiência representado por esta nova moenda em relação às anteriores. Ademais, a eficiência do sistema de entrosas variava em virtude da força motriz utilizada: hidráulica ou animal. Sobre esta diferença, diz Ruy Gama: “(...) um engenho de almanjarras, trabalhando 24 horas, produzia 30 arrobas de açúcar, e que, no mesmo tempo, um engenho d'água produzia de 40 a 70 arrobas. (...) As moendas tracionadas por bois, animais fortes mas morosos, girava lentamente. (...) Com a
} 
de continuidade do processo de trabalho. À positividade da máquina-ferramenta somou-se o benefício advindo de mudanças na organização do trabalho, que apenas se fizeram possíveis em virtude daquele aperfeiçoamento técnicoprodutivo. Significa dizer que a força produtiva social do trabalho deve sempre ser pensada em conjunto, mesmo que analítica e temporariamente possamos decompor o meio de trabalho do seu método de trabalho concomitante. Atenhamonos à organização do trabalho aperfeiçoada pela moenda de entrosas. $\mathrm{O}$ novo maquinário altera profundamente o cotidiano de trabalho do segundo escravo, antes responsável por apenas baldear o bagaço. Agora, este escravo torna-se igualmente fixo diante da moenda, com a atribuição de repassar o bagaço entre os rolos. Não se restringe a baldear o objeto de trabalho para o escravo da frente introduzi-lo entre os rolos, pois agora ele mesmo produz alterações no objeto de trabalho a ponto de produzir matéria-prima (caldo). Antes sua participação para a produção do caldo era indireta, figurando como um trabalhador produtivo por ser partícipe de um mecanismo de produção; agora, sua participação neste mecanismo se dá de forma diretamente produtiva, como um órgão que produz matéria-prima na execução de sua operação parcial. Em termos de conjunto, a supressão da necessidade de meramente baldear o bagaço torna o trabalho mais contínuo e intenso à medida que o mecanismo da nova moenda coage por si só os operadores à execução de suas operações, um pari passu ao outro sob pena de interromper o processo ${ }^{9}$. Esta maior continuidade sedentária, por conseguinte, destrói "a tensão e o impulso dos espíritos vitais, que encontram sua recreação e seu estímulo na própria mudança de atividade" (MARX, 1983, p. 270).

Em síntese, o aumento da produtividade advém da maior eficiência do meio de produção e do processo de trabalho a ele associado, ocasionando uma força produtiva inovadora em relação àquela anteriormente existente.

Como ambos operadores "permaneciam fixos em frente à moenda, um de cada lado, repetindo milhares de vezes ao dia os mesmos movimentos" (FERLINI, 1988, p. 118), o trabalho deles adquiria maior continuidade à medida que os poros (descontinuidades) então existentes são dissipados, aumentando, por conseguinte, a produtividade do trabalho com a supressão do desperdício de tempo. "O resultado do trabalho de um constitui o ponto de partida para o outro", logo, "Um trabalhador ocupa, portanto, diretamente o outro" (MARX, 1983, p. 273); um

roda d'água o problema era exatamente o oposto. Era preciso reduzir sua velocidade" (GAMA, 1983, p. 133).

${ }^{9}$ Como visto na nota anterior, a intensidade do trabalho dos escravos "metedeiros" também estava diretamente relacionada à força motriz utilizada para acionar a moenda. Na hipótese de uma moenda d'água, a maior velocidade desta exigia ações muito mais rápidas dos escravos, num processo de trabalho repetitivo e enfadonho que conduzia os escravos à exaustão mais rapidamente. 


\section{Manufatura açucareira colonial: constituição, desenvolvimento e particularidade.}

constrange o outro ao trabalho na mesma intensidade para se evitar o descompasso. A constância das operações repetitivas em alta intensidade aliada às longas jornadas de trabalho ocasionava sonolência entre os escravos, tal como relata Antonil:

O lugar de maior perigo que há no engenho é o da moenda, porque, se por desgraça a escrava que mete a cana entre os eixos, ou por força do sono, ou por cansada, ou por qualquer outro descuido, meteu desatentamente a mão mais adiante do que devia, arrisca-se a passar moída entre os eixos, se lhe não cortarem logo a mão ou o braço apanhado, tendo para isso junto da moenda um facão (...) E este perigo é ainda maior no tempo da noite, em que se mói igualmente como de dia, posto que se revezem as que metem cana por suas esquipações, particularmente se as que andam nesta ocupação forem boçais ou acostumadas a se emborracharem (1997, p. 112, grifos nossos).

À medida que o novo maquinário gera uma maior continuidade $\mathrm{e}$ intensidade do trabalho - satisfazendo o anseio do capital mercantil por aumento da produtividade - ele se torna concomitantemente mais enfadonho e cansativo para os trabalhadores escravos. Reduzem-se as possibilidades de tempo "recreativo" durante a longa jornada de trabalho, já que aqueles poros descontinuidades - existentes no antigo mecanismo dão lugar a uma utilização contínua e intensa da força de trabalho em benefício da acumulação de capital. A nova engrenagem facilita o controle dos feitores sobre os escravos, afinal, para estes últimos torna-se muito mais difícil remanchar em suas operações - o que era muito mais factível de ocorrer no mecanismo anterior marcado por deslocamentos sucessivos.

A subordinação do trabalho pelo capital é intensificada, mesmo que dentro dos limites próprios da manufatura: a capacidade humana de produção. Assim, a nova maquinaria permite que o capital se imponha sobre os escravos exigindo ritmos até então impensáveis de trabalho, entretanto, sua base antropomórfica fica evidente quando o próprio trabalhador é sugado pelo meio de trabalho. Demonstra-se ao capital nesses casos absurdos que diante da moenda ainda existem seres humanos, que por mais autômatos que se tornem não podem superar os limites do trabalho manual. A estafa resultante da intensidade do trabalho e do prolongamento da jornada configura-se como uma barreira trágica para o capital, sempre ávido por intensificar o trabalho e prolongar a jornada. Não havia ainda, portanto, condições técnicas para que o capital superasse tais limitações, emancipando a produtividade do trabalho de sua barreira humana - manual. Ruy 
Gabriel Magalhães Beltrão

Gama menciona outro limite antropomórfico ao aumento da produtividade na moenda de entrosas. Diz ele:

[...] barreira antropométrica. É que a moenda vertical só permitia a alimentação numa faixa de 1,00 a $1,60 \mathrm{~m}$ de altura, vinculada à altura média do operador. De nada adiantaria agigantar a moenda com rolos de 2 ou $3 \mathrm{~m}$ de altura, mas inaproveitáveis acima da altura acessível a um escravo (GAMA, 1983, p. 183).

A nova maquinaria estava estreitamente vinculada ao trabalho manual que colocava empecilhos para seu crescimento ${ }^{10}$, pois seu tamanho vertical (área de alimentação) era determinado pela estatura média do escravo; para além disso, tornar-se-ia um investimento de capital inócuo, sem retorno econômico. Não obstante o recrudescimento da subsunção do trabalho ao capital, este último se deparou com barreiras antropomórficas que apenas seriam ultrapassadas no século XIX com a moenda de três rolos horizontais ${ }^{11}$.

A importância secundária que a maquinaria desempenha no período manufatureiro também se aplica aos engenhos ${ }^{12}$, mas é interessante ressaltar que $a$ inovação na máquina de extração de caldo criou as condições indispensáveis para que esta manufatura se aprimorasse. Aprimoramento manufatureiro significa intensificação na decomposição das atividades, tendo em vista o surgimento de trabalhadores detalhistas - ainda que parcialmente no caso da produção escravista colonial - que se tornam mais produtivos à medida que se unilateralizam, aumentando-se, por conseguinte, a produtividade do trabalhador coletivo combinado. Justamente o

10 Além dos limites determinados pela capacidade humana, subjetiva, a própria máquinaferramenta possuía limites característico do período manufatureiro. As moendas de entrosas eram fabricadas com madeira, que por vezes recebiam revestimento metálico para aumentar a vida útil. Ainda assim, a pressão aplicada à cana-de-açúcar era muito limitada caso se compare com as moendas de aço do século XIX. Por fim, a força-motriz que acionava tais moendas eram típicas do período manufatureiro: força hidráulica ou tração animal.

11 Tais moendas - filhas da revolução industrial européia - sobrepujaram a limitação antropométrica ao crescimento de sua área de alimentação, agigantando-se horizontalmente à medida que vários trabalhadores poderiam alimentá-la concomitantemente. Ademais, “a grande vantagem dessas moendas foi a de permitir a automatização (...) A alimentação automática através de esteiras transportadoras" (GAMA, 1983, p. 183), permitindo ao capital a redução de custos com força de trabalho e a imposição do ritmo de moagem que bem lhe interessasse.

12 Partindo da conceituação de maquinaria dada por Marx em O Capital, Ruy Gama chega à conclusão de que "A única máquina empregada no engenho era a moenda" (1983, p.338). Somente esta possuía as três partes constituintes de uma maquinaria: força motriz (podendo ser hidráulica ou animal), mecanismo de transmissão e a máquina de trabalho. 


\section{Manufatura açucareira colonial: constituição, desenvolvimento e particularidade.}

sistema de entrosas permitiu este recrudescimento da divisão do trabalho na etapa de cozimento do caldo, afinal, à maior vazão gerada de matéria-prima fez-se necessário o aumento da produtividade na etapa subseqüente. Como a inovação tecnológica no engenho se restringiu à casa de moenda, a resposta a ser dada para o volume crescente de caldo de cana se deu, exclusivamente, em torno do aprimoramento manufatureiro - não havendo, portanto, inovações tecnológicas na etapa de cozimento.

A complexificação da etapa do cozimento se exemplifica bem na reestruturação arquitetônica vivenciada pelos engenhos, pois à medida que a quantidade de caldeiras foi aumentando tornou-se impreterível o surgimento de uma "casa de caldeiras", separada - porém contígua - da "casa de moenda" e da própria fornalha. Os engenhos do início do século XVIII - tal como o engenho Sergipe do Conde descrito por Antonil - não guardam muita semelhança com aquele espaço uniforme dos engenhos precursores; a intensificação da divisão do trabalho não permitia mais aquela uniformidade, tanto em decorrência do aumento do número de recipientes, trabalhadores e da própria produção, quanto em função da necessidade do capital em controlar o trabalho em cada uma das etapas da fabricação.

O aumento da vazão de caldo quebrou a proporcionalidade consolidada até então entre a moenda e a cozinha, abrindo-se a necessidade de se edificar uma nova proporção entre as distintas etapas da fabricação. Os senhores de engenho se viram acossados a aumentar os investimentos em capital constante materializado em caldeiras (feitas de cobres), ferramentas variadas - apropriadas a cada uma das etapas do cozimento do caldo - e mesmo na edificação autárquica da cozinha. As soluções tomadas foram eminentemente quantitativas, sem que tenha havido inovações tecnológicas tanto no cozimento quanto na purgação do açúcar. A multiplicação das caldeiras foi uma resposta positiva ao aumento da vazão de caldo, proporcionando maior continuidade à fabricação como um todo, sem que tenha havido, entretanto, transformações qualitativas na técnica de fabrico do açúcar. Apenas no final do século XIX é que as máquinas e aparelhos industriais chegam à cozinha do engenho.

Diz Antonil que "têm os engenhos reais ${ }^{13}$ dois ternos [de cobres] sempre em obra, porque de outra parte não poderiam dar vazão ao caldo que vem da moenda" (1997, p. 117); tais engenhos reais eram todos movidos a água, o que proporcionava maior velocidade na rotação dos rolos e, por conseguinte, maior

13 “A 'realeza' dos engenhos não decorria da grandiosidade das máquinas e instalações dos engenhos d'água [...]. É no uso das águas - que por serem do patrimônio Real, como estabeleciam as Ordenações - ou pela caracterização de um direito real (direito sobre coisa), inerente ao usufruto dos rios e riachos. [...] Não era real por ser grande mas podia ser grande e vantajoso se fosse real. A roda d'água era o mais potente dos motores de engenho" (GAMA, 1983, p. 130). 
rendimento diário na extração de caldo em relação aos engenhos de tração animal (ou almanjarras). Estes últimos além de morosos ainda eram prejudicados na continuidade da produção, já que tinham que substituir a cada duas ou três horas (no máximo) a dupla de bois de tração - sob pena de matá-los de estafa.

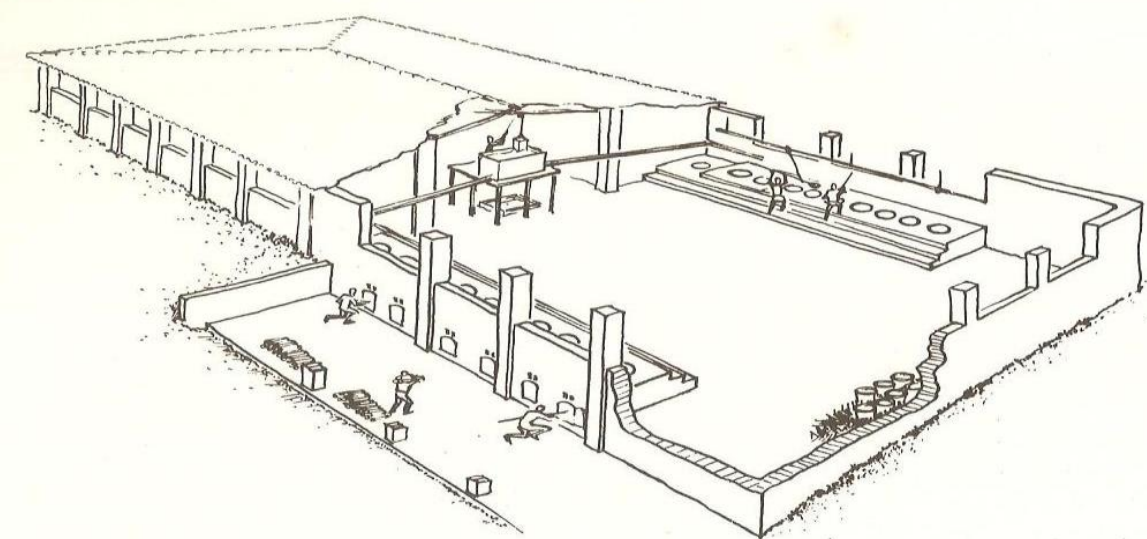

Ilustração 4 - Casa de caldeiras (cozinha) de um engenho real com dois ternos de cobre. Arquitetonicamente, na parte de cima encontra-se a casa de moenda, separada por paredes da casa de caldeiras. Fora desta última vê-se também a casa de fornalhas (Fonte: GAMA, 1983 , p. 257).

Voltando ao engenho real descrito por Antonil, observa-se que a sua moenda hidráulica exigiu o investimento em dois ternos de cobre, cada qual com oito recipientes, totalizando, portanto, dezesseis cobres. As duas caldeiras verificadas no engenho representado por Stradanus dão lugar a dois ternos com oito recipientes cada um, passando a matéria-prima legada pela moenda por todos eles, o que proporcionava continuidade ao processo produtivo. Todas as operações da moagem e da cozinha eram executadas simultaneamente, cada qual legando o objeto de trabalho ao trabalhador subseqüente, numa seqüência temporal de operações justapostas no espaço. A experiência fixou uma nova proporção entre a moenda e a cozinha: na hipótese da primeira ser hidráulica, dois ternos de cobre eram necessários para manter o fluxo contínuo da manufatura, caso contrário a etapa de extração de caldo sofreria bastante com as paralisações à espera de reais necessidades da cozinha. Esta proporção não era válida, porém, para os engenhos de almanjarras, onde a vazão de caldo era menor, exigindo-se uma cozinha de menor porte com um único terno de cobres.

A decomposição do trabalho artesanal é imposta pelo capital pelo fato de aumentar a produtividade do trabalho, tanto das forças produtivas individuais 


\section{Manufatura açucareira colonial: constituição, desenvolvimento e particularidade.}

quanto do trabalhador coletivo combinado como um todo. Em um dado espaço de tempo maior quantidade de mercadorias será produzida na hipótese da produção ser baseada na divisão do trabalho, sendo esta produtividade acrescida à medida que a divisão do trabalho é intensificada. Daí resulta que o aprimoramento manufatureiro da cozinha do engenho não se configurou como um mero aumento da capacidade de produção: o que ocorreu não foi simplesmente o crescimento da quantidade de meios de produção (capital constante) e de trabalhadores (capital variável), repetindo-se o estágio manufatureiro então vigente (vide Stradanus). Caso tivesse havido tãosomente aumento da capacidade de produção na etapa de cozimento - sem haver, portanto, modificações para aprimorar o método manufatureiro de trabalho e a produtividade - , os senhores de engenho teriam apenas feito investimentos para edificar uma cooperação simples: várias duplas de trabalhadores (cozinhadores) num mesmo espaço executando cada qual as mesmas funções e de forma desconexa. Teríamos uma multiplicação do método de trabalho dos primeiros engenhos, com várias duplas de caldeiras e trabalhadores operando lado a lado, autarquicamente, tal como numa cooperação simples. À imatura divisão manufatureira do trabalho dos primeiros engenhos não teria ocorrido um aprimoramento manufatureiro, mas, ao contrário, uma mera estagnação organizativa que representaria, consequentemente, uma estagnação produtiva.

Ao contrário, o aumento da capacidade de produção resultou da intensificação do método manufatureiro de trabalho, percorrendo o objeto de trabalho paulatinamente os oito recipientes que eram trabalhados cada qual por um trabalhador parcial. Portanto, o aumento da produção foi consequência de um aumento da força produtiva do trabalho ${ }^{14}$; a acentuada divisão manufatureira do trabalho se expressa na execução de atividades parciais qualitativamente distintas em tempos menores, proporcionando operações mais céleres e uma produtividade acentuada, que se fez refletir em uma produção maior. Não ocorreu, portanto, uma estagnação na produtividade da manufatura açucareira, mas sim o seu progresso.

Cada um dos oito recipientes era destinado a operações específicas e parciais; após a conclusão em cada uma destas, era o objeto de trabalho transladado para o recipiente seguinte. Deste fluxo contínuo resultava o aumento da produtividade dos trabalhadores escravos parciais, que se materializava numa maior produção diária de açúcar - isto do ponto de vista do produto, do valor de uso. Do ponto de vista do capital, a massa de mais-valia foi expandida através da ampliação da produtividade de cada trabalhador parcial, que na manufatura orgânica está diretamente relacionada ao aumento do número de trabalhadores

14 "Entendemos aqui por aumento da força produtiva do trabalho em geral uma alteração no processo de trabalho, pela qual se reduz o tempo de trabalho socialmente necessário para produzir uma mercadoria, que um menor quantum de trabalho adquira portanto a força para produzir um maior quantum de valor de uso" (MARX, 1983, p. 251). 
parciais trabalhando de forma coletiva ${ }^{15}$. $\mathrm{O}$ aprimoramento manufatureiro do engenho potencializou a taxa de mais-valia de cada escravo, obtendo, por conseguinte, altíssimas massas de mais-valia ao final de cada dia de trabalho, assim como a maior produtividade de cada trabalhador se materializava numa produção maior de açúcar. A citação abaixo de Florestan Fernandes sintetiza bem os ganhos de produtividade obtidos pela produção manufatureira escravista colonial. Diz ele:

Boa parte da análise de sua formação [excedente colonial] se funda na ideia de que ele resultava, pura e simplesmente, da extensão da jornada de trabalho associada ao controle coercitivo do trabalho escravo. No entanto, o que é específico da formação da mais-valia absoluta da produção escravista não são esses dois elementos, quase sempre típicos das fases de implantação ou de escassez da força de trabalho escrava. O elemento específico consiste no trabalho combinado, que sem criar exigências de intervenção no nível técnico permitia aumentar a produtividade. O próprio uso do controle coercitivo da violência não se prendia somente à necessidade de intensificar a jornada de trabalho. Ele procedia do fato que o trabalho combinado acarretava uma disciplina que tirava da violência e da força bruta o caráter de fim em si (FERNANDES, 2010, p. 50, grifo nosso).

A partir desta reflexão podemos concluir que "os aspectos negativos derivados do trabalho escravo foram compensados pelas vantagens organizativas

15 “(...) a divisão manufatureira do trabalho desenvolve o crescimento do número de trabalhadores empregados numa necessidade técnica. (...) Com a parte variável tem de crescer também a parte constante do capital, além do volume das condições comuns de produção, como construções, fornos etc., nomeadamente também e com muito mais rapidez que o número de trabalhadores, a matéria-prima" (MARX, 1983, p. 282). Como vimos acima, a necessidade de inversão inicial para a compra dos escravos e a própria condição escravista da força de trabalho - excedendo às necessidades da produção - são fatores que tendem a restringir a intensificação da divisão do trabalho e da especialização e, por conseguinte, o aumento da produtividade. Tal como dissemos no primeiro capítulo, a não existência de manufatura açucareira trabalhada por assalariados não permite que comprovemos este lei tendencial da produção escravista mercantil no interior da parte fabril dos engenhos, nosso objeto de estudo. A escassez de divisão do trabalho ficava mais evidente em outras atividades integrantes na parte agrícola ou em atividades acessórios da unidade socioeconômica. 


\section{Manufatura açucareira colonial: constituição, desenvolvimento e particularidade.}

(...)" (GORENDER, 2011, p. 135) do engenho. O problema congênito da "ignorância, [d]a incapacidade, [d]a falta de atenção e cuidado com que se maneja a fabricação do açúcar" (PRADO Jr., 2011, p. 146), próprios à mão de obra servil, foram contornados pela organização manufatureira, demonstrando que as relações escravistas de produção eram compatíveis com o progresso técnico (vide moendas de entrosas) e organizativo característico da fase do capitalismo mercantil - do qual a economia colonial figurava como peça importantíssima. Além de compatível, defendemos a hipótese de que a divisão do trabalho no interior da parte fabril pode ser considerada como uma condição sine qua non para a utilização da mão de obra escrava, pois somente desta forma a fabricação do açúcar perde o seu caráter artesanal, reduzindo cada escravo à condição de trabalhador parcial desprovido de potências intelectuais ${ }^{16}$. Escravidão e artesanato são duas categorias que, a rigor, se repelem, sendo exceção a existência de escravos artesãos durante a escravidão moderna, baseada na utilização intensiva de mão de obra servil. Para satisfazer o anseio de produzir açúcar em larga escala com trabalhadores desqualificados e que têm ojeriza ao trabalho - em virtude de sua condição servil, não por preguiça como a ideologia escravocrata apregoava -, o capital mercantil tinha que dissociar dos trabalhadores "Os conhecimentos, a compreensão e a vontade", opondo-lhes "as forças intelectuais do processo material de produção como propriedade alheia e poder que os domina" (MARX, 1983, p. 283). Como veremos mais à frente, este processo intrínseco ao desenvolvimento manufatureiro da via clássica ao capitalismo atinge o paroxismo na manufatura escravocrata.

A produção mercantil em larga escala baseada na escravidão surge como uma demanda do capital mercantil na modernidade, que impõe um "sentido à colonização" que contrasta em absoluto com outras formas de produção - como a produção camponesa, por exemplo. A exigência pela produção em larga escala se materializou em grandes propriedades e na utilização intensiva de força de trabalho. No que tange ao beneficiamento da cana-de-açúcar, apenas a cooperação baseada na divisão do trabalho estaria em consonância com aquela exigência, visto

${ }^{16}$ Com isso não pretendemos absolutizar a separação entre trabalho manual e trabalho intelectual, caso contrário estaríamos acreditando na completa "robotização" dos sujeitos, o que teria consequência inclusive sobre a história - tornando-a desprovida de resistência e possibilidades de vir-a-ser. Apenas queremos mostrar que o objetivo deliberado da classe escravista era excluir a subjetividade dos escravos do processo produtivo, aspirando tornálos verdadeiras máquinas. Algo, inclusive, muito mais intenso do que o processo europeu mostrado por Marx. Como isso é impossível, além da resistência, os escravos findavam assimilando conhecimentos no dia-a-dia da produção, mesmo que a formação e ascensão técnica nunca fosse o interesse dos senhores. 
que maximizava a capacidade de beneficiamento por unidade produtiva ${ }^{17}$. Ademais, como a escravidão foi também uma exigência imperiosa do "sentido da colonização", este tipo de relações de produção apenas produziria os efeitos esperados caso fosse inserido numa força produtiva adaptável à condição servil e ignorante do escravo. O processo de dissociação entre o trabalho manual e o trabalho intelectual é marcante na manufatura e, no caso do escravismo, esta separação entre o conhecimento do fabrico do açúcar e as operações manuais parciais era uma condição para que o trabalho escravo fosse viável economicamente.

A escravidão apenas responderia às necessidades do capital mercantil na hipótese de se articular a uma força produtiva que a tornasse producente, capaz de contornar seus aspectos contraproducentes, como ignorância estrutural ${ }^{18}$ e a aversão ao trabalho inerente à condição servil. A desqualificação e o desestímulo dos escravos ao trabalho, resultante de sua condição social, também foi um fator que impulsionou a busca por uma força produtiva apta a contornar esta tendência à baixa produtividade do trabalho forçado; a divisão do trabalho foi a resposta positiva dada para driblar aquele problema, permitindo o aumento da produtividade no interior da produção fabril. Tal adaptação entre a escravidão e a manufatura é que tornou a produção colonial apta a cumprir os desígnios do capital mercantil com o sistema colonial, produzindo um excedente econômico cuja maior parte era apropriada pelos grandes comerciantes, metropolitanos ou não. Afinal, "O capital mercantil tecia as redes que não deixavam escapar os peixes grandes e o seu apetite era insaciável" (FERNANDES, 2010, p. 51).

\section{Mestre do açúcar}

De acordo com a nossa análise, o mestre do açúcar personifica a particularidade da manufatura açucareira que advém de dois fatores: por um lado, da carência de condições técnicas que possibilitassem maior controle sobre os processos físico-químicos da produção, afetando-a com uma contingência não existente normalmente em outras oficinas; por outro lado, das relações escravistas

\footnotetext{
17 A pequena produção agrícola de cana-de-açúcar era beneficiada na produção artesanal das chamadas engenhocas. Definitivamente, esta forma de produção - artesanal e familiar contrasta com o sentido desenvolvido pela colonização.

18 Entendemos por ignorância estrutural o aviltamento sistemático do desenvolvimento humano do escravo imposto pela sociedade escravocrata, que figurava como necessária à sua reprodução, justificando a escravidão entre os brancos livres e buscando introduzir a consciência reificada e reificante entre os próprios escravos. "A 'socialização parcial' do escravo fazia com que, em geral, seu adestramento fosse incompleto, limitado como era à transmissão de técnicas e à inculcação de normas e valores que motivavam o negro apenas para o trabalho rude das fazendas e do charque" (CARDOSO, 2011, p. 179).
} 


\section{Manufatura açucareira colonial: constituição, desenvolvimento e particularidade.}

de produção que também deixam suas marcas indeléveis sobre esta manufatura orgânica, marcadamente no rigor excessivo existente na separação entre trabalho manual e trabalho intelectual. A materialidade da matéria-prima impunha significativa imprevisibilidade à produção, cabendo ao mestre do açúcar intuir as variáveis atuantes e tomar as devidas iniciativas, responsabilidade esta inconcebível de ser partilhada com os escravos "caldeireiros" e "tacheiros", tanto pelo embrutecimento estrutural imposto a esta classe social quanto pelo fato desta ser encarada pelos senhores como inimiga da produção, devendo, por conseguinte, ser alijada ao máximo de operações que requeressem conhecimentos que extrapolassem a mera habilidade manual com suas ferramentas de trabalho. Enquanto res, instrumentum vocale, os escravos da planta fabril deveriam ser adestrados para que executassem suas operações parciais manuais com a maior destreza e celeridade, excluindo-lhes, contudo, do aprendizado de tudo que extrapolassem este objetivo. A particularidade da manufatura açucareira é consequência, portanto, de dois fatores de naturezas distintas: um de origem técnica intransponível naquele momento histórico pré-industrial, marcadamente manufatureiro; já o outro era de natureza social, resultado das relações escravistas de produção impostas pelo capital mercantil que hipertrofia a oposição entre as forças intelectuais e os trabalhadores, caso a comparemos com as manufaturas que compuseram a via clássica de desenvolvimento capitalista .

Não havia entre os escravos a autonomia para determinar a consecução de suas atividades parciais, pois isto era determinado exclusivamente pelo mestre do açúcar. É como se eles recebessem o produto parcial do companheiro antecedente, soubessem as atividades manuais que deveriam realizar, sem, contudo, possuírem o conhecimento e a autoridade para determinar a conclusão de suas operações parciais. A sombra do mestre do açúcar era uma presença constante para esses trabalhadores, único dotado de conhecimento necessário para determinar o término de cada operação. A imprevisibilidade imposta pela matéria-prima não permitia o pré-estabelecimento rigoroso das ações componentes de cada operação parcial, seja em função do tempo ou do número de ações a serem repetidas (número de escumas, por exemplo). Cada caldo deixa a sua marca individualizante e o responsável por determinar as ações dos caldeireiros e tacheiros era o mestre. Só este tem a experiência, inteligência e diligência necessária para saber propor as ações condizentes em cada caso, por exemplo, o quantum de decoada será aplicada ao caldo ou o tempo que este permanecerá no fogo em cada um dos recipientes.

Trata-se - a nosso ver - de uma peculiaridade do engenho em relação às características gerais da manufatura evidenciadas por Marx. Em regra, a unilateralização dos trabalhadores no mecanismo do trabalhador coletivo combinado não os expropria das forças intelectuais necessárias à determinação da consecução de suas atividades parciais; mesmo o mestre artesão europeu sendo rebaixado à condição de trabalhador qualificado parcial, mantém ele tanto a 
capacidade de executar as funções manuais partícipes de sua atividade parcial, quanto o conhecimento necessário para determinar a completa execução da mesma. Diferentemente, os trabalhadores parciais da cozinha do engenho são expropriados, inclusive, desta capacidade - aparentemente simples - de determinar a plena execução de sua transformação sobre a matéria. Longe de possuírem o domínio sobre o saber-fazer global do açúcar, estão também distantes de deterem o saber-fazer sobre aquela fração a que são responsáveis. Tornam-se autômatos executores manuais de uma operação parcial que não lhes compete determinar o seu término (conclusão). A separação entre o trabalho manual e o trabalho intelectual é muito mais profunda do que na manufatura européia, onde a mutilação do trabalhador - convertido em trabalhador parcial - não exclui a sua formação para além do estritamente necessário e a própria capacidade de determinar a conclusão de sua operação parcial. Ao escravo, ao contrário, é negada qualquer formação que extrapole o estritamente necessário ${ }^{19} \mathrm{e}$ a própria capacidade de determinar a conclusão de sua atividade. A incognoscibilidade da própria atividade parcial é uma particularidade do trabalhador escravizado na manufatura açucareira.

O mestre do açúcar possui este status pelo fato do processo produtivo ter base técnica artesanal, tornando-se imprescindível à fabricação o acúmulo de conhecimento oriundo da experiência para a consecução exitosa da produção. Este título não é à toa, mas porque tem papel ativo da fabricação do açúcar: a ele cabe, de fato, grande parte do mérito do produto final. Deve ter inteligência e experiência acumulada na fabricação de maneira a saber as necessidades distintas dos diversos tipos de cana; uma cana de várzea ou de outeiro geram caldos diversos que modificam significativamente o processo produtivo, aumentando ou diminuindo o tempo que o caldo ferverá em cada uma das caldeiras e tachas. Não se trata, portanto, de uma experiência da fabricação do açúcar stricto senso, interna à cozinha, mas uma experiência regional ${ }^{20}$ capaz de proporcionar maior previsibilidade a um processo produtivo profundamente maculado pela contingência.

O acúmulo de conhecimentos necessários ao fabrico do açúcar é negado aos "caldeireiros" e "tacheiros", que se limitam à imprescindível execução de suas operações manuais parciais, operações estas que são desconsideradas pelo jesuíta italiano. À medida que os conhecimentos necessários ao fabrico do açúcar são excluídos dos escravos e o processo produtivo físico-químico exige uma constante

19 “Considerado em sua massa, sobretudo nos domínios agrícolas, o escravo era um mau trabalhador, apto apenas a tarefas simples, de esforço braçal sem qualificação. Suas possibilidades de progresso técnico - afora exceções singulares - só podiam ser extremamente limitadas. No Brasil, por sinal, a legislação do Império proibiu que escravos recebessem instrução sequer nas escolas primárias, equiparando-os aos doentes de moléstias contagiosas. [...] Assim, ao contrário dos operários livres, os escravos eram incapazes de ascensão técnica em massa" (GORENDER, 2011, p. 106).

${ }^{20}$ Cf. FERLINI, 1988, p. 135. 


\section{Manufatura açucareira colonial: constituição, desenvolvimento e particularidade.}

intervenção cognitiva, tal aporte necessário de conhecimentos deve se concentrar necessariamente em algum sujeito. $\mathrm{O}$ mestre do açúcar acumula em si este saber que é negado aos escravos, aos trabalhadores manuais, e dado a natureza do processo produtivo ele tem, de fato, participação ativa no produto final. Esta concentração do saber em torno de um único sujeito é consequência: 1) da base técnica artesanal de uma produção complexa - físico-química - que exige um conhecimento prático-intuitivo acumulado para acompanhar/determinar todo o processo produtivo decomposto; a complexidade envolvida no fabrico do açúcar sobre bases artesanais exige a concentração do saber em alguns sujeitos, que se incumbem da responsabilidade pelo produto final; 2) ainda que a concentração deste saber em torno do mestre tenha explicação na base técnica envolvida, a grau excessivo desta concentração apenas é explicável em virtude das relações de produção; os escravos são inseridos na manufatura como meras peças de uma engrenagem, fragmentos de uma totalidade que lhes era alheia e desconhecida; até aí nada de particular em relação à manufatura baseada no trabalho livre; a peculiaridade reside no fato de que as forças intelectuais que se dissociam do trabalhador livre na manufatura, opondo-lhes como propriedade alheia que os domina, dissociam-se na manufatura escravista de uma maneira muito mais intensa determinada pela condição objetiva e subjetiva do escravo enquanto coisa. Assim, a necessidade da figura do mestre nos engenhos coloniais é oriunda da base técnica artesanal e das relações sociais de produção que reificam ao extremo os seres humanos ${ }^{21}$, opondo rigidamente trabalho manual e trabalho intelectual.

${ }^{21}$ A regra na sociedade escravista reside na incompatibilidade entre trabalho escravo e trabalho especializado, que requer conhecimentos e habilidades especiais. Tal regra se explicitava com mais vigor nas unidades produtivas rurais do que nas cidades, onde os senhores tendiam a qualificar seus escravos para que pudessem ser lucrativos. Excluindo-se estes últimos, na produção rural a grande massa dos escravos era composta por trabalhadores desprovidos de maiores qualificações, adaptados ao trabalho rústico do campo. Ainda que os escravos tenham se inserido numa organização qualitativamente superior àquela existente no campo, adaptando-se à produção manufatureira dos engenhos, mesmo aí a grande maioria era apenas adestrada para serviços manuais parciais e que não requeriam conhecimentos especiais. A condição objetiva e subjetiva do escravo no interior do escravismo engendrava uma forte tendência para que seus trabalhos fossem desta natureza, carentes de habilidades e conhecimentos especiais. Todavia, a existência de escravos em postos como mestres do açúcar e purgadores demonstra que tal incompatibilidade não era absoluta. Ainda assim, a regra se afirmava quando se verifica que a tendência era de que tais postos fossem ocupados por trabalhadores livres. A rigidez na oposição entre trabalho manual e trabalho intelectual se manifesta na dificuldade relatada pelos autores para se achar mestres do açúcar, o que evidencia o grau de embrutecimento a que eram submetidos os escravos do engenho, pois apesar de trabalharem constantemente no beneficiamento do caldo não conseguiam alcançar o posto de mestre. Apenas em meados do século XIX é que esta rígida separação se atenua um pouco dado a tendência notória de 
Diante de um processo produtivo complexo (físico-químico) e de uma base técnica artesanal, certamente a possibilidade de qualificação progressiva - mesmo que dentro de limites impostos pela relação capital - por parte de trabalhadores livres parciais iria se refletir em ganhos de produtividade, maior aprimoramento das ferramentas e responsabilidade partilhada pela consecução do produtor final, aspectos estes que restringiriam a dependência extrema em relação ao mestre do açúcar e que tendiam a ossificar a produção. A estagnação produtiva dos engenhos se evidencia na rotina e na ignorância reinante nos séculos XVIII e XIX, que, segundo Caio Prado, tem nas relações escravistas o principal responsável por este estado de coisas, pois se trata de uma produção "fundado no trabalho ineficiente e quase sempre semibárbaro do escravo africano. Seria difícil realizar coisa de muito melhor com trabalhadores dessa natureza" (PRADO JR., 2011, p. 145). O que ocorreu foi a formação de uma força produtiva adequada à utilização de uma mão de obra desqualificada e avessa ao trabalho, mecanismo este que reproduziu por séculos esta situação nada inventiva e pouco produtiva. Além do bloqueio que o trabalho escravo impôs ao desenvolvimento das forças produtivas, os efeitos nefastos do antigo sistema colonial garantiam a acumulação externa e a permanente carência de capitais no interior da colônia. Assim, o espólio colonial somado ao trabalho escravo formou uma estrutura econômica cujo fundamento residia na extração absoluta da mais-valia, bloqueando o desenvolvimento das forças produtivas e o aumento significativo da produtividade que caracteriza uma economia capitalista plena.

\section{Referências Bibliográficas}

ANTONIL, André João. Cultura e Opulência do Brasil. - Belo Horizonte: Ed. Itatiaia; São Paulo: Ed. Da Universidade de São Paulo, 1997.

BELTRÃO, Gabriel Magalhães. A economia colonial e a particularidade da manufatura açucareira. Maceió-AL: Programa de Pós-Graduação em Sociologia do Instituto de Ciências Sociais da Universidade Federal de Alagoas. Dissertação de Mestrado defendida em 2012.

CARDOSO, Fernando Henrique. Capitalismo e escravidão no Brasil meridional: o negro na sociedade escravocrata do Rio Grande do Sul. 6 $6^{\text {a }}$ ed. - Rio de Janeiro: Civilização Brasileira, 2011.

FERLINI, Vera Lúcia Amaral. Terra, Trabalho e Poder. São Paulo, Ed. Brasiliense, 1988.

fim da escravidão, quando os senhores passam a buscar de forma inédita o interesse do escravo pela produção através de estratégias como, por exemplo, a promessa de concessão de manumissão. 
Manufatura açucareira colonial: constituição, desenvolvimento e particularidade.

FERNANDES, Florestan. Circuito Fechado: quatro ensaios sobre o "poder institucional". São Paulo-SP, Editora Globo, 2010.

GAMA, Ruy. Engenho e Tecnologia. São Paulo, Livraria Duas Cidades, 1983.

GORENDER, Jacob. O Escravismo Colonial. São Paulo, Editora Fundação Perseu Abramo, 2010.

MARX, Karl. O Capital: crítica da economia política. Tradução de Regis Barbosa e Flávio R. Kothe. - 3. ed. - São Paulo: Abril Cultural, (Os economistas). Livro primeiro, Volume I, Tomo 1, 1983.

PRADO JR., Caio. Formação do Brasil Contemporâneo. São Paulo, Companhia das Letras, 2011. 